\title{
Investigation of TiN Coated CBN and CBN Cutting Tool Performance in Hard Milling Application
}

\author{
Fatih Taylan ${ }^{1}$ - Oğuz Çolak ${ }^{1, *}$ - Mehmet Cengiz Kayacan² \\ ${ }^{1}$ Suleyman Demirel University, Faculty of Technology, Department of Manufacturing Engineering, \\ Turkey \\ ${ }^{2}$ Suleyman Demirel University, Faculty of Engineering, Department of Mechanical Engineering, Turkey
}

Cubic Boron Nitride (CBN) and TiN Composite Coated CBN combines the thermal stability, super abrasiveness and cost effectiveness for hard machining applications. This paper reports the results of a study addressing wear performance of these CBN and TiN based coated CBN inserts (SNMN090308) for face milling of $61 \mathrm{HRC}$ hardened 90MnCrV8 tool steel. Machining test conditions are obtained after dynamic stability simulation of cutting tools and machine tools. The tool wear and cutting forces are also analyzed and the results are presented.

(C) 2011 Journal of Mechanical Engineering. All rights reserved.

Keywords: tool wear, hard milling, CBN tools, coated CBN

\section{INTRODUCTION}

Hard milling has been recently employed to hardened steels (>30 HRC) used for dyes and mould making industry [1].

Generally, in hard milling research fields have focused on tool life [2], surface integrity [3], white layer effects [4], chip formation [5], cutting force models [6], stability of hard milling [6] and optimal cutting parameters [7]. However, very few studies have dealt specially with the dynamic cutting mechanisms induced by hard milling such as the effects of machine tool stability. Better understanding of machining stability can lead to a better process economics, increased process stability, improved tool life, reduced tooling costs and enhanced surface integrity and component performance.

Many researchers have studied cubic boron nitride $(\mathrm{CBN})$ tools in the hard milling of steel alloys [8] to [12]. Generally CBN cutting tools have greater wear resistance than other tool materials due to their high degree of hardness [8]. Raghavan [10] was used PCBN to face mill AIS1 HI3 (48 to $50 \mathrm{HRC}$ ) tool steel at cutting speeds of 100 to $200 \mathrm{~m} / \mathrm{min}$, feed of $0.1 \mathrm{~mm} /$ tooth and $1.0 \mathrm{~mm}$ depth of cut. Heath et al. [11] recommended the use of PCBN at a cutting speed of $180 \mathrm{~m} / \mathrm{min}$, a feed of $0.2 \mathrm{~mm} /$ tooth and 1.0 mm depth of cut to face mill cold work tool steel (60 HRC). Nakagawa et al. [12] has reported the effect of cutting fluid when high speed ball nose end milling $57 \mathrm{HRC}$ tool steel AISI D2 using polycrystalline cubic boron nitride (PCBN) tools. The application of a water-based cutting fluid led to catastrophic tool failure due to thermal shock, however, indirect supply of oil on the surface of the work material, rather than directly at the cutting edge, resulted in a longer tool life as compared to dry cutting. They have reported a feed/tooth of $0.05 \mathrm{~mm}$, and axial/radial depths of cut of 0.05 and $0.2 \mathrm{~mm}$, respectively, a length cut of $400 \mathrm{~m}$ for a flank wear of approximately 0.1 $\mathrm{mm}$ using oil as the cutting fluid at a cutting speed of $222 \mathrm{~m} / \mathrm{min}$.

58 HRC AISI D2 hardened tool steel is face milled by Koshy et al. [13] with a round CBN insert. They found acceptable tool life (43 $\mathrm{cm}^{3}$ of removed material) together with excellent surface finish in the range of 0.1 to $0.2 \mu \mathrm{m}$ in Ra. This study points out that tool life would need to be extended to make the process economically viable.

CBN and coated CBN tools are still very expensive and it is difficult to find better cutting performance [14]. In our study the use of different CBN Grade is proposed.

In this study, cutting performance of the TiN coated CBN and CBN cutting tools for 61 HRC hardened $90 \mathrm{MnCrV} 8$ cold work tool steel face milling is investigated with considering hard milling stability analysis. Wear performance 
of $\mathrm{CBN}$ and TiN based coated $\mathrm{CBN}$ inserts (SNMN090308) for face milling of the hardened tool steel is examined. The tool wear formation and cutting forces are also analyzed and the results are presented.

\section{EXPERIMENTAL METHODOLOGY}

Machining experiments are performed on a Harford VMC 1020 machining centre to ensure precisely computer controlled cutting conditions. The depth of cut, the feed rate and cutting speed are selected by simulating analytical chatter stability analysis. Stability analysis procedure of hard face milling test is shown in Fig. 1.

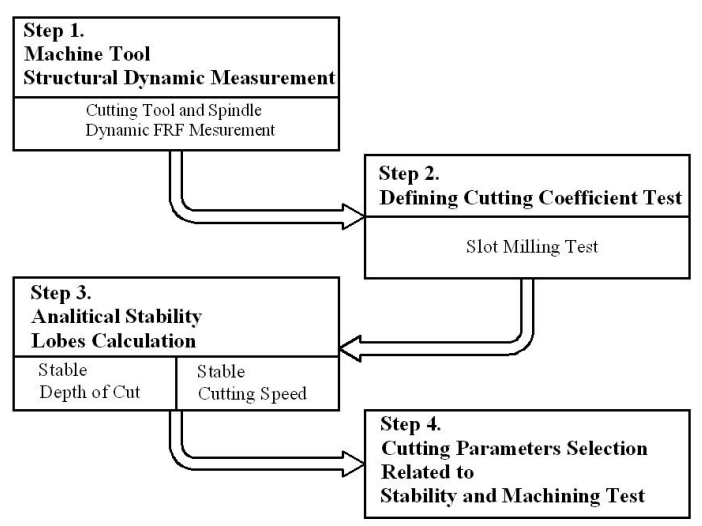

Fig. 1. Procedures of face milling stability analysis

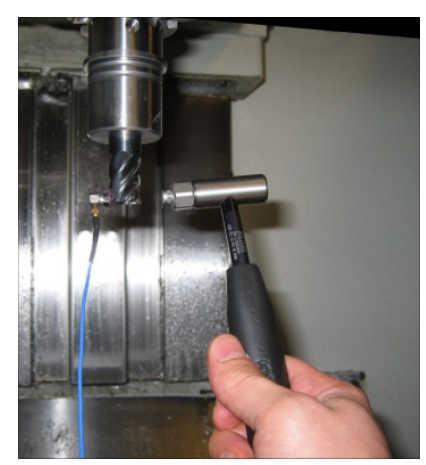

Fig. 2. Structural dynamic measurement of cutting tool

From Fig. 1 it is seen that Step-1 machine tool-workpiece structural dynamic measurement is done using the tap testing method. Fig. 2 shows tap testing of cutting tool.
$\mathrm{X}$ and $\mathrm{Y}$ direction of cutting tool dynamic characteristics is measured with tap testing. 2000 N Kistler 9722A Hammer and 100 g/V sensitivity accelerometer is used for tap testing. Frequency response function calculation (FRF) cutting tool is calculated in both directions using CutPRO MALTF software.

In Step-2 cutting coefficients are defined. In this step, the slot milling test is done to define the average cutting coefficient. Table 1 shows the test conditions of hard milling.

Table 1. Average cutting coefficient test conditions [15]

\begin{tabular}{|c|c|c|c|c|}
\hline $\begin{array}{c}\text { Test } \\
\text { no }\end{array}$ & $\begin{array}{c}\text { Feed rate } \\
{[\mathrm{mm} /} \\
\text { tooth] }\end{array}$ & $\begin{array}{c}\text { Spindle } \\
\text { speed } \\
{[\mathrm{rpm}]}\end{array}$ & $\begin{array}{c}\text { Cutting } \\
\text { speed } \\
{[\mathrm{m} / \mathrm{min}]}\end{array}$ & $\begin{array}{c}\text { Axial } \\
\text { depth of } \\
\text { cut [mm] }\end{array}$ \\
\cline { 1 - 2 } 1 & 0.05 & & & \\
\cline { 1 - 2 } 2 & 0.075 & \multirow{2}{*}{850} & \multirow{2}{*}{50.87} & \multirow{2}{*}{0.3} \\
\hline 3 & 0.1 & & & \\
\cline { 1 - 2 } 4 & 0.125 & & \\
\hline 5 & 0.150 & & & \\
\hline
\end{tabular}

Average cutting forces are calculated by using measured cutting forces in three dimensions for each test condition. Average cutting forces are used for calculating average cutting coefficient model [16] which is given in Eq. (1).

$$
\begin{array}{cc}
K_{t c}=\frac{4 \bar{F}_{y c}}{N a}, & K_{t e}=\frac{\pi \bar{F}_{y e}}{N a}, \\
K_{r c}=\frac{-4 \bar{F}_{x c}}{N a}, & K_{r e}=\frac{-\pi \bar{F}_{x e}}{N a}, \\
K_{a c}=\frac{\pi \bar{F}_{z c}}{N a}, & K_{a e}=\frac{2 \bar{F}_{z e}}{N a} .
\end{array}
$$

In Eq. (1), $N$ is the number of teeth, $a$ is axial depth of cut [mm], $\bar{F}_{x c}, \bar{F}_{y c}, \bar{F}_{z c}$ are average cutting force in $x, y$ and $z$ directions respectively (Newton), $\bar{F}_{x e}, \bar{F}_{y e}, \bar{F}_{z e}$ are average edge cutting force in $\mathrm{x}, \mathrm{y}$ and $\mathrm{z}$ directions (Newton), $K_{r c}$, $K_{t c}, K_{a c}$ are cutting coefficients of tool-material interface in radial, tangential and axial directions $\left[\mathrm{N} / \mathrm{mm}^{2}\right], K_{r e}, K_{t e}, K_{a e}$ are cutting tool edge cutting coefficients in radial, tangential and axial directions $[\mathrm{N} / \mathrm{mm}]$.

After the slot milling test, the average cutting coefficient of $90 \mathrm{MnCrV} 8$ is found. Sub indices $(c)$ and $(e)$ represent shear and edge force 
components, respectively. The edge cutting $K_{r e}$, $K_{t e}$ and $K_{a e}$ are constants and related to the cutting edge length $\mathrm{d} S$ given in an infinitesimal length (ds) of a helical cutting edge. The shear force coefficients $K_{r c}, K_{t c}$ and $K_{a c}$ are identified either mechanistically from milling tests conducted at a range of feed rate. Table 2 shows average cutting coefficients.

In Step-3 stability of hard face milling experiment is simulated by using cutting tool frequency response function calculation (FRF) (Step-1) and average cutting coefficients (Step2). Stability simulation is calculated using Eq. (2) [16].

$$
a_{\lim }=-\frac{2 \pi \Lambda_{R}}{N K_{t}}\left(1+\kappa^{2}\right)
$$

Stability lobe diagram is given Fig. 3 .
In Step-4 the tool wear test condition which is given Table 3 is determined after stability simulation. Axial depth of cut is fixed as $0.6 \mathrm{~mm}$ related to stability simulation which is shown in Fig. 3.

The chemical properties of workpiece material are given in Table 4. Workpiece material, steel 90MnCrV8 (AISI - O2, EU - 90MnCrV8) is a cold work tool steel, with high dimensional stability at heat treatment, very high resistance to cracking, high machinability, medium toughness and resistance to wear. Hardness after annealing is max $229 \mathrm{HB}$. After quenching, the hardness achieved may be from 63 to $65 \mathrm{HRC}$. The field of application of $90 \mathrm{MnCrV} 8$ is compress measuring tools, machine knives for the wood, paper and metal industry, cold cutting shear blades, thread cutting tools [17].

Table 2. Average cutting coefficients of $62 \mathrm{HRC} 90 \mathrm{MnCrV8}$ tool steel [15]

\begin{tabular}{|c|c|c|c|c|c|c|}
\hline & $\begin{array}{c}K_{t e} \\
{[\mathrm{~N} / \mathrm{mm}]}\end{array}$ & $\begin{array}{c}K_{r e} \\
{[\mathrm{~N} / \mathrm{mm}]}\end{array}$ & $\begin{array}{c}K_{a e} \\
{[\mathrm{~N} / \mathrm{mm}]}\end{array}$ & $\begin{array}{c}K_{t c} \\
{\left[\mathrm{~N} / \mathrm{mm}^{2}\right]}\end{array}$ & $\begin{array}{c}K_{r c} \\
{\left[\mathrm{~N} / \mathrm{mm}^{2}\right]}\end{array}$ & $\begin{array}{c}K_{a c} \\
{\left[\mathrm{~N} / \mathrm{mm}^{2}\right]}\end{array}$ \\
\hline Average Cutting Coefficients & 581.35 & -724.47 & 158.96 & 3689.11 & -5804.89 & 2257.14 \\
\hline
\end{tabular}

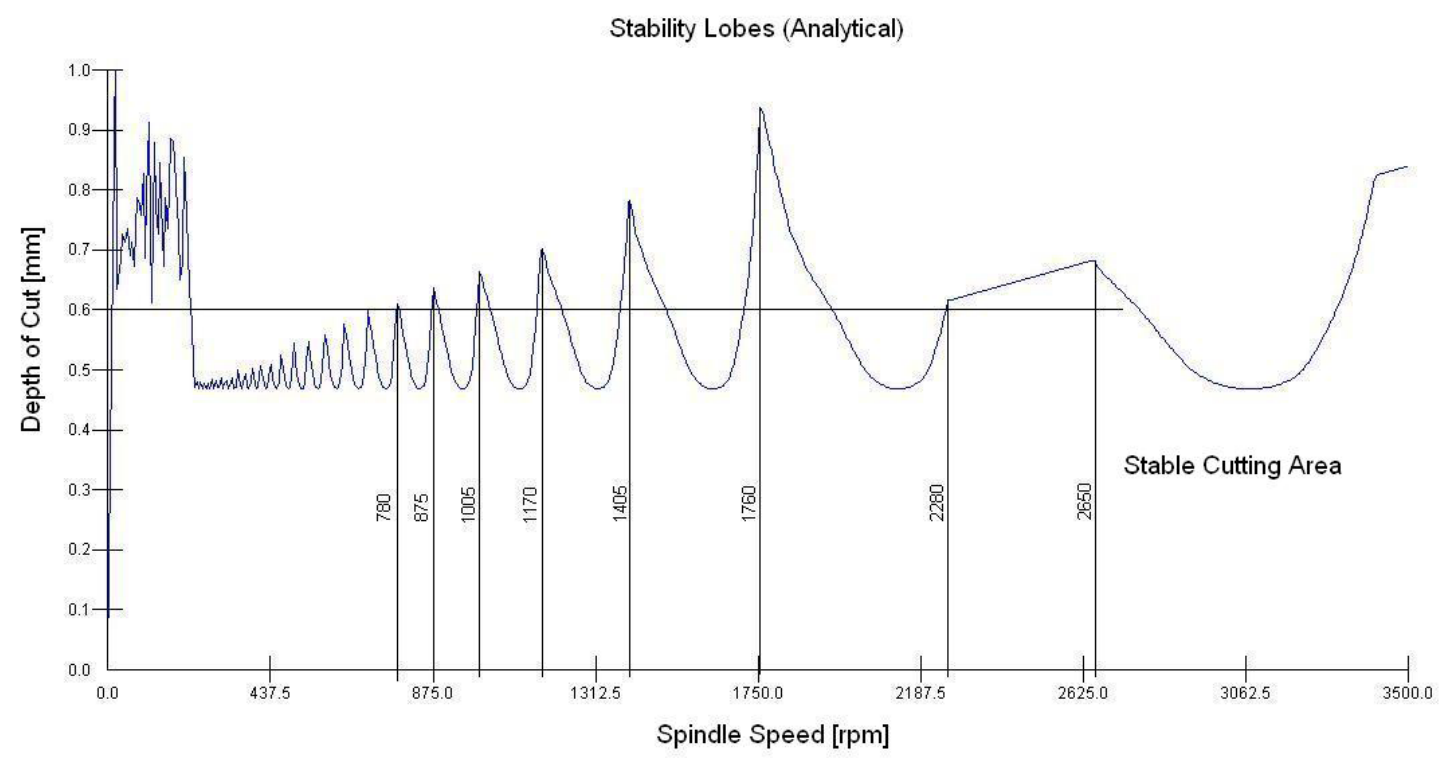

Fig. 3. Analytical Stability Lobes diagram of hard milling test

Table 3. Stable tool wear test conditions for 90MnCrV8 Face milling [15]

\begin{tabular}{|c|c|c|c|c|c|c|c|c|c|}
\hline Spindle speed & $\mathrm{rpm}$ & 2650 & 2280 & 1760 & 1405 & 1170 & 1005 & 875 & 780 \\
\hline Feed rate & $\mathrm{mm} /$ tooth & 0.05 & 0.075 & 0.1 & 0.15 & \multicolumn{1}{|c|}{} \\
\hline
\end{tabular}


The tests were discontinued when a flank wear criterion $V B$ of $700 \mu \mathrm{m}$ was reached. For cutting tool wear test chip volume is fixed 5896.8 $\mathrm{mm}^{3}$. Flank wear measurements were taken in accordance with the International Standard ISO 8688-1 [19] and using the Olympus TM optical microscope and SEM. Cutting forces were recorded for every test in $F_{x}, F_{y}$ and $F_{z}$ directions. For this purpose, a 9257B-type Kistler dynamometer was used.

Two type CBN tool is tested in a hard milling test. Properties of cutting tools are given in Table 5.

Table 4. Chemical compositions of $90 \mathrm{MnCrV} 8$ [18]

\begin{tabular}{|c|c|c|c|c|c|c|}
\hline \multicolumn{7}{|c|}{ Chemical Composition (\% weight) } \\
\hline $\mathrm{C}$ & $\mathrm{Si}$ & $\mathrm{Mn}$ & $\mathrm{Cr}$ & $\mathrm{P}$ & $\mathrm{S}$ & $\mathrm{V}$ \\
\hline 0.88 & 0.29 & 2.07 & 0.26 & 0.024 & 0.009 & 0.08 \\
\hline
\end{tabular}

\section{RESULTS AND DISCUSSION}

\subsection{Tool Wear}

Damage of the cutting tools over the entire range of cutting conditions was mainly in the form of chipping. Chipping tool wear measurement ISO 8688 standard of face milling conditions is given in Table 6.
Hard milling of $90 \mathrm{MnCrV} 8$ cold work tool steel by CBN is characterized by the flow of chips at very high temperature and extremely deformed signs of intensive shearing at cutting edge (Fig. 4).

In this study a different type of chipping tool wears is investigated. This wear formation is given in Table 7. As seen from Table 7 TiN Composite Coated CBN grade cutting tools are four times braked than CBN grades. Milling operations are known as interrupt cutting so that TiN Composite Coated CBN grades is not useful for hard milling application.

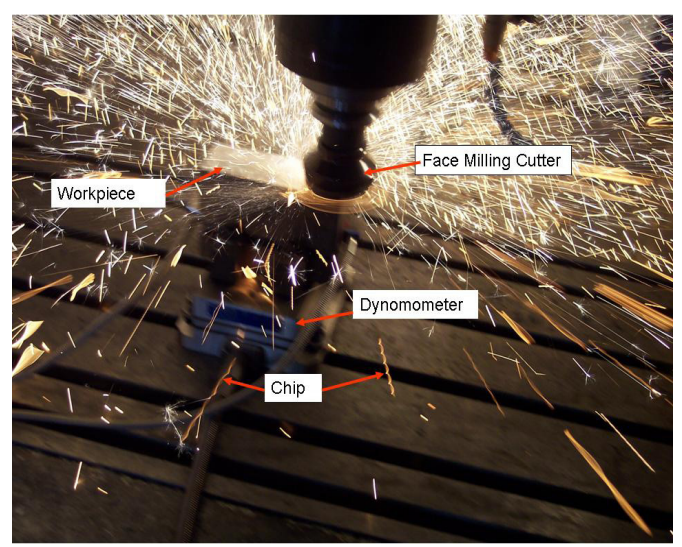

Fig. 4. Heat dissipation through chip while machining, $V c=278.1 \mathrm{~m} / \mathrm{min}$

Fig. 5a shows the change in depth of the chipping wear with a cutting distance for the

Table 5. Cutting tools properties [20]

\begin{tabular}{|c|c|c|}
\hline Tool Properties & CBN300 Grade & CBN300P Grade \\
\hline ISO CODE & SNEN0903ENE-M06 & SNMN090308 \\
\hline Compositions & $\begin{array}{c}\text { CBN content approx. } 90 \text { vol \% } \\
\text { Average starting grain size }(\mu \mathrm{m})-22 \\
\text { Binder }-\mathrm{Al} \text { ceramic } \\
\text { Format }- \text { Solid }\end{array}$ & $\begin{array}{c}\text { CBN content approx. } 90 \text { vol \% } \\
\text { Average starting grain size }(\mu \mathrm{m})-22 \\
\text { Binder }- \text { Al ceramic } \\
\text { Format }- \text { Solid Coated Ti }(\mathrm{C}, \mathrm{N})+(\mathrm{Ti}, \mathrm{Al}) \\
\mathrm{N}+\text { TiN with a total thickness of } 2-4 \mu \mathrm{m}\end{array}$ \\
\hline $\begin{array}{l}\text { Physical } \\
\text { Properties }\end{array}$ & $\begin{array}{l}\text { Knoops hardness GPa }-30.4 \\
\text { Thermal conductivity }\left[\mathrm{Wm}^{-1} \mathrm{~K}^{-1}\right] \\
\left(20^{\circ} \mathrm{C}\right)-130\end{array}$ & $\begin{array}{c}\text { Knoops hardness } \mathrm{GPa}-30.4 \\
\text { Thermal conductivity }\left[\mathrm{Wm}^{-1} \mathrm{~K}^{-1}\right] \\
\left(20^{\circ} \mathrm{C}\right)-130\end{array}$ \\
\hline Tool Geometry & $\begin{array}{c}\text { Size } \\
L-9.525 \mathrm{~mm} \\
s-3.18 \mathrm{~mm} \\
B-0.9 \mathrm{~mm} \\
r_{e}-0.8 \mathrm{~mm} \\
\text { Rake angle }-0^{\circ}\end{array}$ & $\begin{array}{c}\text { Size } \\
L-9.525 \mathrm{~mm} \\
s-3.18 \mathrm{~mm} \\
B-0.9 \mathrm{~mm} \\
r_{e}-0.8 \mathrm{~mm} \\
\text { Rake angle }-0^{\circ}\end{array}$ \\
\hline
\end{tabular}


Table 6. ISO 8688 Face milling chipping measurement standard

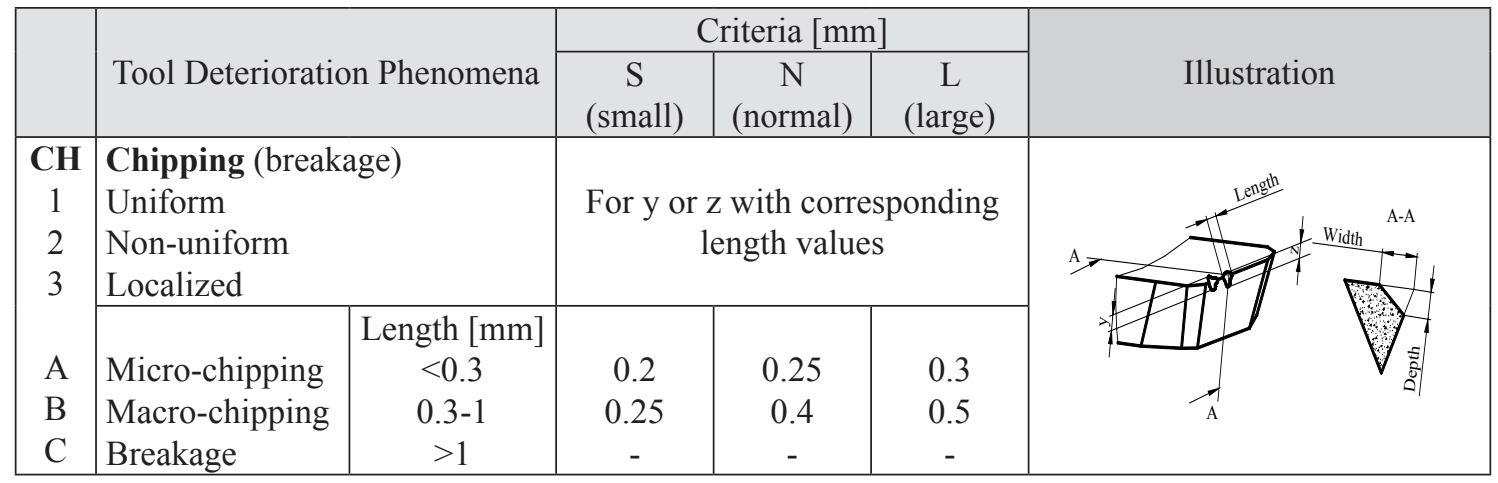

Table 7. Tool wear type of TiN coated CBN and CBN tool in hard milling conditions

\begin{tabular}{|c|c|c|}
\hline & Breakage ISO type C & Macro chipping ISO type B \\
\hline CBN tool & 2 tools & 30 tools (1 Small, 13 Normal, 16 Large) \\
\hline TiN Composite Coated CBN & 9 tools & 23 tools (2 Small, 10 Normal, 11 Large) \\
\hline
\end{tabular}

a)

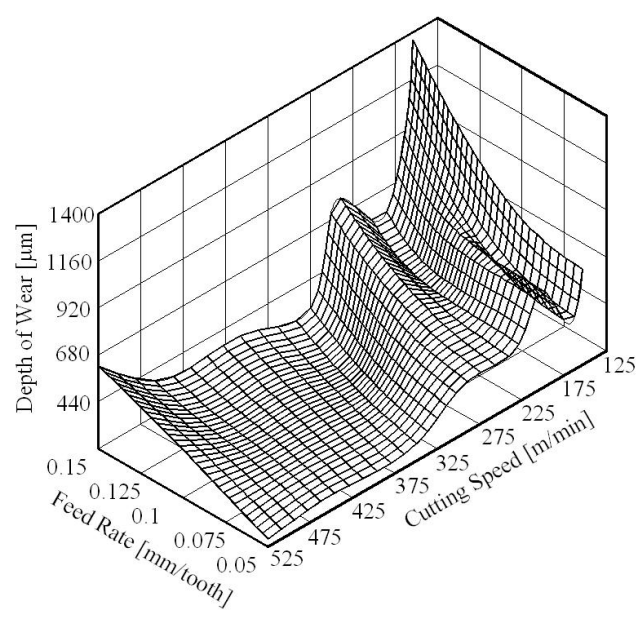

b)

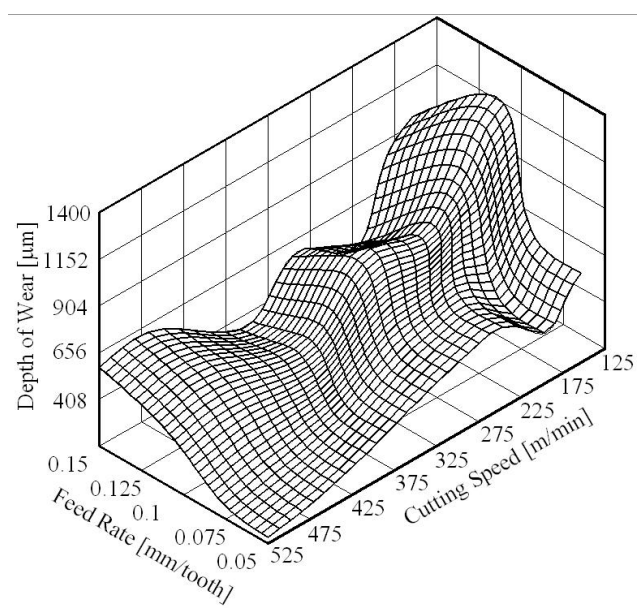

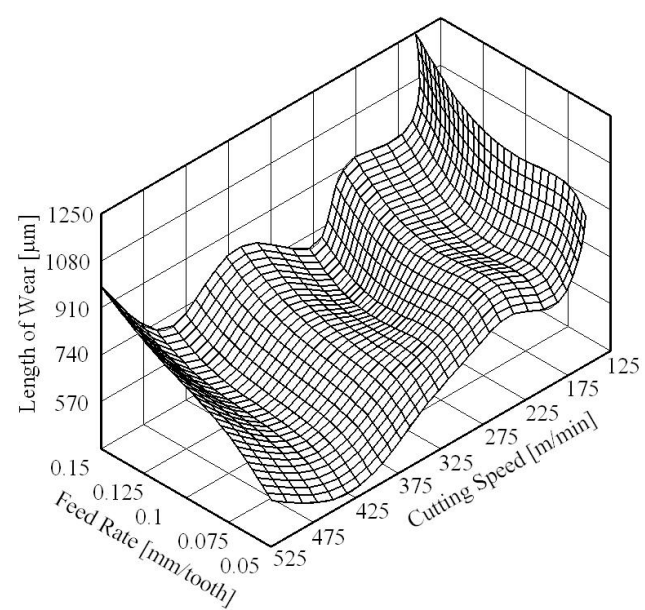

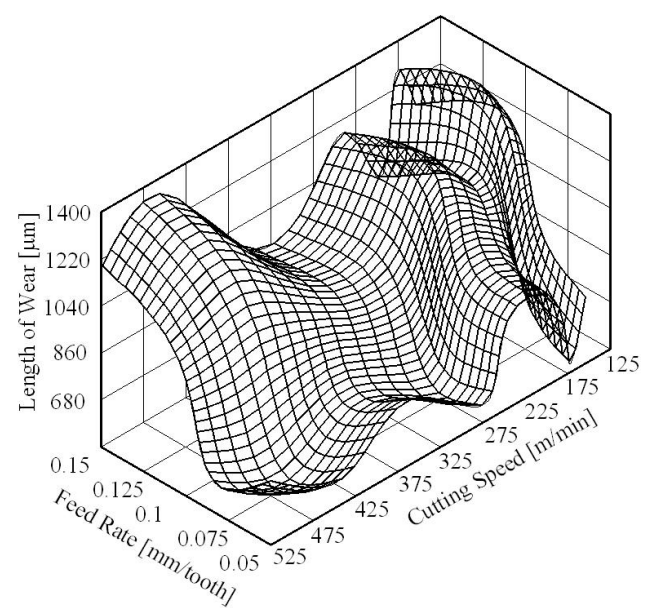

Fig. 5. Wear depth and length in the hard milling tests at various feed [mm/tooth] and cutting speeds [m/min]; a) CBN tools, b) coated Ti $(C, N)+(T i, A l) N+T i N C B N$ tools 

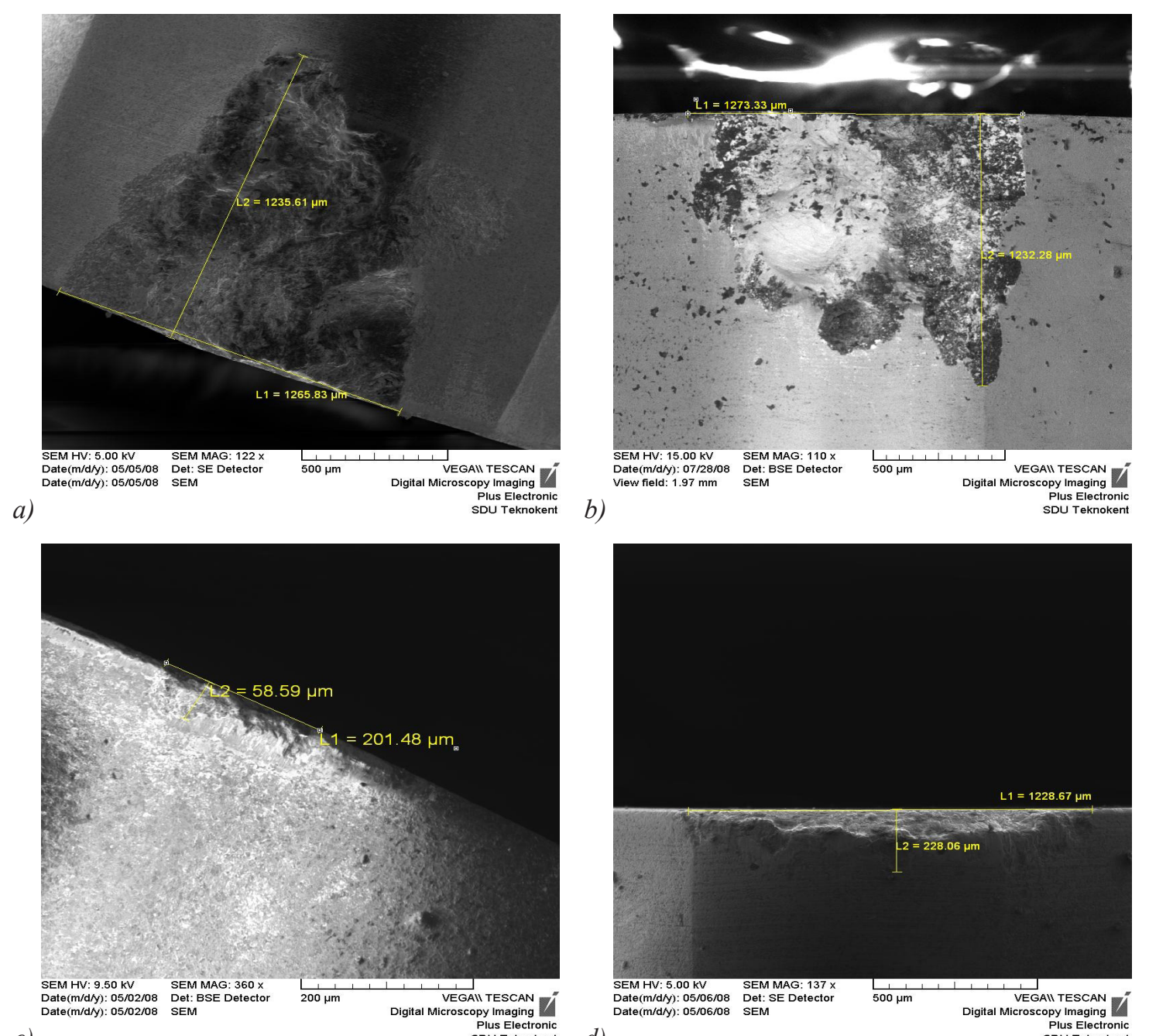

c) Plus Electronic
SDU Teknokent

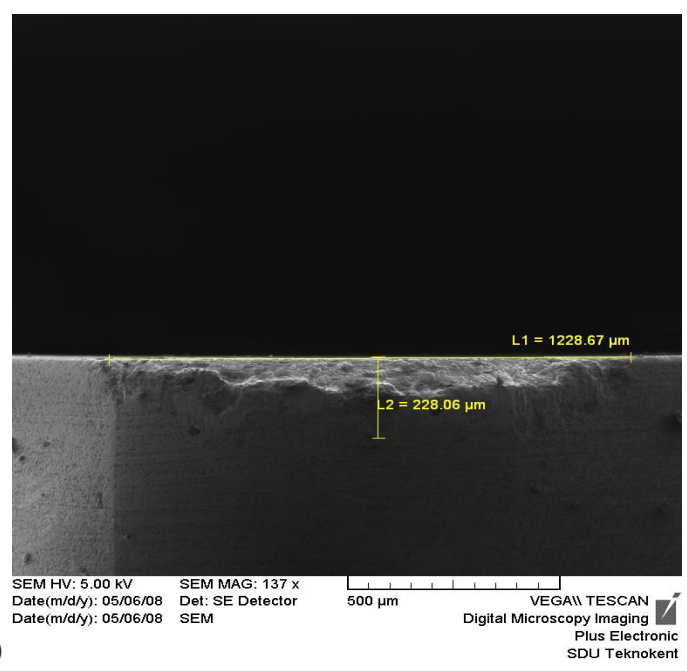

Fig. 6. Tool wear SEM photo images; a) Maximum tool wear for six insert CBN tools $\left(v_{c}=154.4 \mathrm{~m} / \mathrm{min}\right.$, $f=0.15 \mathrm{~mm} /$ teeth), b) Maximum tool wear for six insert Coated Ti $(C, N)+(T i, A l) N+$ TiN CBN tools $\left(v_{c}=154.4 \mathrm{~m} / \mathrm{min}, f=0.1 \mathrm{~mm} /\right.$ teeth $\left.), c\right)$ Minimum tool wear for six insert $C B N$ tools $\left(v_{c}=524.5 \mathrm{~m} / \mathrm{min}\right.$, $f=0.05 \mathrm{~mm} /$ teeth), d) Minimum tool wear for six insert Coated Ti $(\mathrm{C}, \mathrm{N})+(\mathrm{Ti}, \mathrm{Al}) \mathrm{N}+\mathrm{TiN} C B N$ tools

$$
\left(v_{c}=524.5 \mathrm{~m} / \mathrm{min}, f=0.05 \mathrm{~mm} / \text { teeth }\right)
$$

tools grade $\mathrm{CBN}$ in the machining of $90 \mathrm{MnCrV} 8$ cold work tool steel at various depths of feed and cutting speeds. The change in the chipping wear depth with various feed and cutting speeds for coated $\mathrm{Ti}(\mathrm{C}, \mathrm{N})+(\mathrm{Ti}, \mathrm{Al}) \mathrm{N}+\mathrm{TiN}$ can be seen in Fig. 5b. It was found that at low cutting speed and high feed rate, the chipping wear increased significantly and at high cutting speed and low feed rate tool wear is decreased. As seen in Fig. 3 CBN grade is more stable depth and length tools wear rates than TiN Composite Coated CBN due to more breakage of TiN Composite Coated CBN.
The chipping wear decreased significantly when the cutting speed was increased from 300 to $525 \mathrm{~m} / \mathrm{min}$ in both tool types. SEM images of maximum tool wear rate for each inserts are given Fig. 6. Maximum tool wear is obtained at low cutting speed which is $154.4 \mathrm{~m} / \mathrm{min}$. For both cutting tool grade minimum tool wear is obtained at 524.5 cutting speed and $0.05 \mathrm{~mm} /$ teeth feed rate. Maximum tool wears and minimum tool wear SEM photographs are illustrated in Fig. 6. 


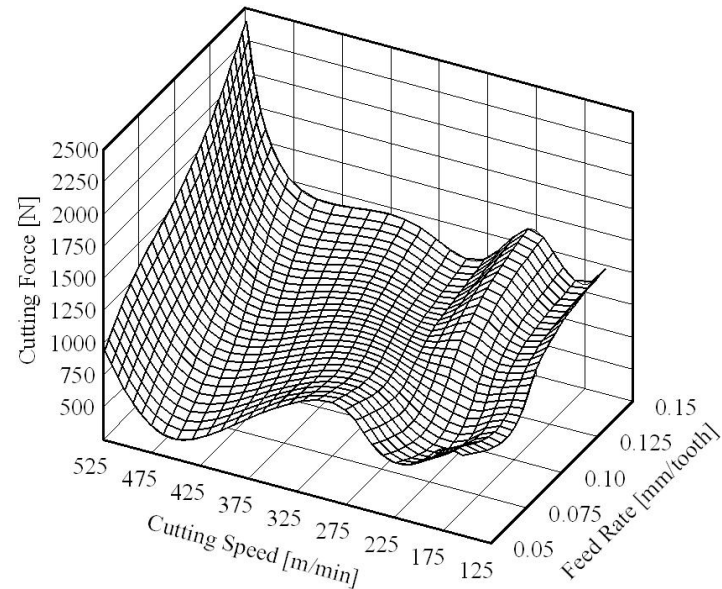

a)

Fig. 7. Average feed cutting forces $(F x)$, a) with different cutting speed and feed rate for test conditions CBN tool, b) coated Ti $(C, N)+(T i, A l) N+$ TiN CBN tool

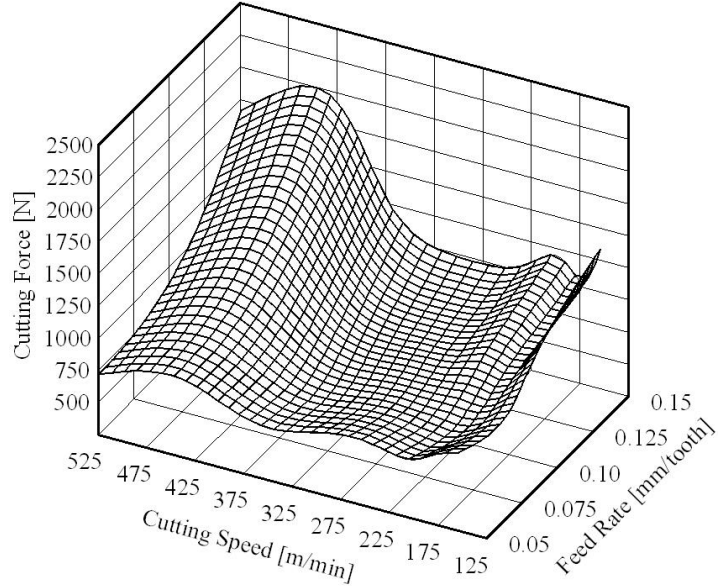

\subsection{Cutting Forces}

The average cutting forces (feed forces $F_{x}$ ) obtained with tool grades $\mathrm{CBN}$ and coated $\mathrm{Ti}(\mathrm{C}, \mathrm{N})+(\mathrm{Ti}, \mathrm{Al}) \mathrm{N}+\mathrm{TiN} \mathrm{CBN}$ are compared in Figs. $7 \mathrm{a}$ and $\mathrm{b}$. It was found that when the chipping was increased (due to an increase feed rate or a reduction in the cutting speed), it also coincided with an increase in the cutting forces.

\section{CONCLUSIONS}

The following results can be extracted from the hard face milling of $90 \mathrm{MnCrV} 8$ tool steel by $\mathrm{CBN}$ and $\mathrm{PCBN}$ insert tools.

The face milling of $90 \mathrm{MnCrV} 8$ tool steel in the hardened state (61 HRC) were shown tool life values of $<260 \mathrm{~mm}$ length of cut. Little difference was found in tool wear between the $\mathrm{CBN}$ insert tools and coated $\mathrm{Ti}(\mathrm{C}, \mathrm{N})+(\mathrm{Ti}, \mathrm{Al}) \mathrm{N}+\mathrm{TiN} \mathrm{CBN}$ insert.

An analysis of flank wear patterns indicated that macro chipping, governing mechanisms were responsible for tool wear. PCBN tools failed by fracture of the cutting edge.

In CBN cutting tools wear test $6.25 \%$ tool breakage is investigated. However, coated $\mathrm{Ti}(\mathrm{C}, \mathrm{N})$ $+(\mathrm{Ti}, \mathrm{Al}) \mathrm{N}+\mathrm{TiN}$ CBN cutting tools wear test $28.13 \%$ tool breakage was investigated. 
high speed milling of P20 steel. Advanced Materials Research, vol. 24-25, p. 45-54.

[5] Dolinsek, S., Ekinovic, S., Kopac, J. (2004). A contribution to the understanding of chip formation mechanism in high-speed cutting of hardened steel. Journal of Materials Processing Technology, vol. 157-158, p. 485490.

[6] Altintas, Y., Weck, M. (2004). Chatter stability of metal cutting and grinding. CIRP Annals - Manufacturing Technology, vol. 53, no. 2, p. 619-642.

[7] Ghani, J.A., Choudhury, I.A., Hassan, H.H. (2004). Application of Taguchi method in the optimization of end milling parameters. Journal of Materials Processing Technology, vol. 145 , no. 1, p. $84-92$.

[8] Camuscu, N., Aslan, E. (2005). A comparative study on cutting tool performance in end milling of AISI D3 tool steel. Journal of Materials Processing Technology, vol. 170, p. 121-126.

[9] Ateş, S., Er, A.O., Aslan, E., Camuşcu, N. (2006). Sertleştirilmiş P20 Kalip Çeliğinin Kübik Bor Nitrür Kesici Takimlarla Yüksek Hizlarda Frezelenmesi, 12th International Congress of Mechanical Design and Manufacturing, Kusadasi. (In Turkish)

[10] Raghavan, K. (1988). Face milling of hardened die steel using CBN tooling. MSc. Project Report, Graduate School of Machine Tool and Manufacturing Technology, Department of Mechanical Engineering, University of Birmingham.

[11] Heath, P.J. (1987). Ultra hard tool materials, in machining, ASM Metals Handbook, 9th ed., vol. 16, p. 105-117.
[12] Nakagawa, T., Ikeda, T., Matsuoka, T. (1995). High speed milling of steel and tool life. Proceedings of the $8^{\text {th }}$ International Conference of the Tool, Die and Mould Industry, Barcelona.

[13] Koshy, P., Dewes R.C., Aspinwall D.K. (2002). High speed end milling of hardened AISI D2 tool steel (similar to 58 HRC). $J$ Mater Process Technology, vol. 127, p. 266273.

[14] Seco Tools (2007). Secomax PCBN technical information leaflet 00:I, available online at http://www.secotools.com (accessed on 10/2009)

[15] Taylan, F. (2009). The Determination of Tool Wear Behavior in Milling of Hard Materials. $\mathrm{PhD}$ Thesis, Graduate School of Natural and Applied Sciences, Suleyman Demirel University.

[16] Altıntaş, Y. (2000). Manufacturing Automotion. Cambridge University Pres, Vancouver.

[17]Ekinovic, S., Dolinsek, S., Begovic, E. (2005). Machinability of $90 \mathrm{MnCrV} 8$ steel during high-speed machining. Journal of Materials Processing Technology, vol. 162.163, p.603-608.

[18] K720 DIN 1.2842 (90MnCrV8) Böhler tool steels www.osmanlicelik.com (accessed on 10/2009).

[19] International Standard ISO 8688-1, Tool life testing in milling-face milling, $1^{\text {st }}$ ed. 198905-01.

[20] Seco Tools Milling Tool Catalogue. (2008). 